\title{
LONGWALL MINING-INDUCED FAULT REACTIVATION AND DELAYED SUBSIDENCE GROUND MOVEMENT IN BRITISH COALFIELDS
}

\author{
Laurance J Donnelly ${ }^{1}$, Martin G Culshaw ${ }^{2}$ and Fred G Bell ${ }^{2}$ \\ ${ }^{1}$ Halcrow Group Ltd., Deanway Technology Centre, Wilmslow Road, Handforth, Cheshire, \\ SK9 3FB, UK. \\ ${ }^{2}$ British Geological Survey, Keyworth, Nottingham, NG12 5GG, UK.
}

\begin{abstract}
Faults located in areas undergoing mining subsidence during the longwall extraction of coal seams may undergo reactivation. This has been observed and documented throughout the UK (and in other major coalfields around the world) over the past 150 years. The impact of subsidence induced fault reactivation may cause moderate to severe damage to foundations, houses, buildings, structures and underground services, as well as damage to agricultural land through disruption of drainage and alteration of the gradient. Monitoring of faults, as they are affected by undermining, has resulted in a better understanding of fault reactivation mechanisms and of the various styles of fault reactivation, in different geological and mining settings.
\end{abstract}

The duration of fault reaction is difficult to determine due to the lack of observational data. However, trough subsidence following longwall extraction of coal is rapid, often being completed within weeks to months. This is commonly followed, shortly afterwards, by a period of delayed subsidence known as residual subsidence, which in the British Coal Measures, rarely accounts for more than $10 \%$ of the total subsidence. In many circumstances, where faults are not present, residual subsidence is complete within four months, although several cases have been recorded where subsidence effects were still being observed more than two years after mining had finished. Generally, it is accepted that fault reactivation sometimes may extend over the period of residual subsidence.

In parts of the abandoned or partially active coalfields in the UK, relatively smaller ground movements have been observed in the vicinity of fault outcrops many years after mining has ceased. The reasons for this are not fully understood. Nonetheless, prolonged periods of fault reactivation may have an important effect on land use and construction. 
The objectives of this paper are to consider fault reactivation and, in particular, to document examples of post-mining ground movements around fault outcrops and to discuss possible causal mechanisms. Features associated with these movements include increases in elevation of the ground surface and deformation (e.g. subsidence, graben, scarps or steps, compression and tension) of the ground surface in the vicinity faults. These features, in turn, may be associated with groundwater or mine water rebound.

\section{Introduction}

Faults located in areas where longwall mining subsidence is taking place may be susceptible to reactivation. This may result in the generation of grabens, scarps (often termed steps or break lines), fissures or compression humps at the ground surface. Fault scarps in the coalfields of the UK vary from subtle topographic deflections and flexures only recognizable across agricultural land or roadside verges, to distinct, high-angled fault scarp walls 3-4 m high and at least $4 \mathrm{~km}$ long. They occur in rural and urban parts of Britain in both the exposed and concealed coalfields (Figure 1). The consequences of fault reactivation may be damage to surface structures, services, utilities and transport networks. Frequently, reactivated faults also have disrupted agricultural land through alteration of drainage and gradient. In addition, fault reactivation may cause the failure of natural slopes, high-walls in opencast mines, engineered cuttings and embankments, and can influence stream and groundwater flows.

Fault reactivation that is contemporaneous with mining subsidence occurs because of the release of strain accumulations along the fault zone. This can cause shear displacements, resulting in uneven subsidence on one side of the fault relative to the other (Figure 2 and Figure 3). Unfortunately, the duration of fault reactivation associated ground movements is difficult to assess because of the lack of reliable observational data. Public safety often is of direct concern when incremental ground-surface displacements occur rapidly, as when blocks of ground move into open-spaces of underground workings.

\section{Overview of mining subsidence}

The majority of the coal mined in Britain in the twentieth century and at present, although now greatly reduced in amount, was and is by longwall mining. Longwall mining involves the total extraction of a series of panels of coal that are separated by pillars whose width is small compared to overburden thickness (Bell and Donnelly 2006). The coal is exposed at a 
face 30 to $300 \mathrm{~m}$ in width between two parallel roadways. The roof is artificially supported temporarily at the working face and in, and near, the roadways. After the coal has been won and loaded the artificial face supports are advanced, leaving unsupported rock, in the areas where coal has been removed, to collapse. Subsidence at the surface more or less follows the advance of the working face and may be regarded as immediate and contemporaneous with mining, producing more or less direct effects at the surface. The subsidence that occurs over a completely mined out area in a seam is trough-shaped and extends outwards and upwards, beyond the limits of mining in all directions (Anon, 1975). Hence, the surface area affected by ground movement is greater than the actual area worked in the seam. The boundary of the surface area affected is defined by the angle-of-draw (or angle-of-influence which varies from $8^{\circ}$ to $45^{\circ}$ from the vertical at the edge of the panel, depending on the geologic, structural and lithologic characteristics of the coalfield (Figure 5).

The lag-time taken for arrival of subsidence at a ground-surface point (P) to be completed is approximately inversely proportional to the rate of forward advance of the workings (Wardell, 1954; Figure 6). The upward transmission of movement to the surface is almost instantaneous, commencing when the strata at seam horizon begin to relax, following the advancement of the temporary roof supports. In practice, measurable subsidence appears to occur when the face comes to be within a horizontal distance of $0.75 \mathrm{~d}(\mathrm{~d}=$ depth to coal seam) of a given point, $\mathrm{P}$, on the surface and reaches approximately $15 \%$ of maximum when the face is directly below P. For all practical purposes, the magnitude of vertical subsidence is complete when the face has advanced for a lateral distance of about $0.8 \mathrm{~d}$ beyond P. Residual subsidence then occurs, those points that are subsiding fastest experiencing the most residual subsidence.

Residual subsidence may continue after instantaneous subsidence takes place for periods, normally, of up to two years or more. The magnitude of residual subsidence is proportional to the rate of subsidence of the surface and is related to the mechanical properties of the rocks above the coal seam concerned. For instance, strong rocks produce more residual subsidence than weaker ones. Residual subsidence rarely exceeds $10 \%$ of total vertical subsidence, if the face is stopped within the "critical area” (the planar area of the workings that bring about complete subsidence at one point on the ground surface) but falls to 2 to $3 \%$ if the face has passed the critical width (the critical width is the width of the longwall panel required, so the 
width/depth ratio is just sufficient to allow development of the full potential subsidence, for UK coal mining conditions this corresponds to $\mathrm{w} / \mathrm{h}=1.4$ ). Very occasionally, values greater than $10 \%$ have been recorded. For instance, after a study of five coal mines in Britain, Ferrari (1997) found that residual subsidence ranged from 8 to $45 \%$ of total subsidence and continued for up to 11 years after mining operations ceased. Singh and Singh (1998) noted that residual subsidence in the Kamptee Coalfield, India, varied between 7.4 and $22.4 \%$ of total subsidence and took place in less than two years. According to Yao and Reddish (1994), the maximum residual subsidence in a level seam occurs at the lateral half-subsidence point along a longitudinal line to the workings while along a transverse line it occurs at the centre of the workings. The maximum residual subsidence in an inclined seam occurs at the ribside (edge of the workings) point.

\section{Faults and their reactivation}

In areas where faults do not exist the contributory factors which influence the continuance of subsidence are as follows:

- Depth of workings, in general subsidence ceases sooner in the case of shallow workings.

- Soft coal and soft floor rocks may encourage yielding in the presence of abutment pressure along the extraction edges

- Incomplete roof and floor convergence, which is influenced by the depth of workings and physical properties of the strata.

- Bed separation within an area undergoing subsidence provides the potential for the gradual closure of such voids.

- Changes in the physical support conditions of the goaf area can cause yield and further settlement of the overlying strata

As mentioned, pre-existing faults tend to become the loci of subsidence movement, by concentration of abnormal deformation of the ground surface. Fault reactivation not only occurs simultaneously with mining subsidence but the movement can take place over periods ranging from weeks to years, and may continue after normal subsidence has ceased. It can occur in phases separated by periods of where reactivation of faults ceases until the fault is approached by further longwall panels. Unfortunately, the precise duration of movement is 
impossible to determine. On the other hand, many faults have not reacted adversely when subjected to subsidence (Hellewell, 1988).

The mechanisms involved in mining-induced fault reactivation have been reviewed by Donnelly (1994, 2006). Such reactivation during longwall mining basically is controlled by several inter-related geological and mining factors. The geological factors that influence fault reactivation include the prevailing and pre-existing stress field, the geological history of the fault, the geotechnical properties along the fault (friction, cohesion and pore water pressures), proximity of the fault to the ground surface, the local hydrogeological regime, and the incidence and orientation of discontinuities in adjacent rock masses. In general, it is the main (known sometimes as the principal faults) faults, which define region structural cells (blocks) that have the greatest tendency to undergo reactivation when they are subjected to mining subsidence. In general, main faults tend to have suffered more episodes of incremental displacement and therefore tend to have a lesser degree of inter-surface roughness, thus making them less resistance to forces of shearing. The mining factors that influence fault reactivation are the depth of extraction, the mine and fault geometry, the horizontal distance of the workings to the fault, the rate of mining, the thickness of the extraction, and the history and intensity of mining.

In fact, faults also tend to act as boundaries controlling the lateral extent of the subsidence trough. If a fault is encountered during seam extraction and its throw is large, then if the workings terminate against the fault permanent strains are induced at the surface, which probably are accompanied by severe differential subsidence in the zone of influence of the fault. Indeed, a subsidence step may occur at the outcrop of such faults. When workings terminate against a fault plane that has an angle of hade (the angle between the fault plane and the vertical) larger than the angle-of-draw (the angle between the vertical line at the edge of the mine workings and the line joining this edge to the limit of significant ground movement at the surface (see also Figure 5), then the normal subsidence profile extends to the surface. Conversely, when the hade of the fault is less than the angle-of-draw, the fault determines the extent of the subsidence trough, which in this case is less than that normally expected. Faults are most likely to react adversely (thus being more prone to concentrating displacement on their slip surface) when their hade is less than $30^{\circ}$ (ie. their dip is more than $70^{\circ}$ ), when they have simple form and the material occupying the fault zone does not offer high frictional 
resistance. Fault scarps tend to occur when faults represent single sharp stratal breaks. By contrast, if a fault consists of a relatively wide shatter zone, then the surface subsidence effects usually are less pronounced (Donnelly 1994), due to a tendency to spread the deformation across many smaller surfaces making up the weak-rock zone.

The abnormal subsidence associated with displacement concentrated along faults is influenced by the type of surface rocks (Lee 1965, Phillips and Hellewell 1994, Donnelly 1994). This explains why stepping is not consistent along a fault affected by subsidence. Furthermore, stronger surface rocks, such as some sandstones and limestones, tend to fracture and form blocks that cause more laterally-widespread damage because of the cantilevering effect of the fractured blocks. This may explain the reverse stepping that occurs at times. Where a fault passes through a block jointed formation that outcrops at the surface, then severe fissuring or fracturing can occur at the surface. The fissures generally run parallel to the line of the fault but can occur as broadly as up to $300 \mathrm{~m}$ outwardly away from it. The thickness and nature of the unconsolidated deposits above bedrock also can influence the magnitude of individual fault steps (see below).

The type and extent of subsidence associated with faults also depends on the methods and extent of mining in relation to a particular fault plane. The most notable steps occur when the coal is worked beneath the hade of a fault, because the strain relieving process encourages directly-localised, increased movement along the fault plane, faces in other positions being much less likely to be brought into differential movement. Workings on the upthrown side of a fault are more likely to cause stepping than similar workings on the downthrown side, but this is not always the case. Steps are usually oriented downwards towards the goaf (area of a mine from which coal is removed, causing the roof and mine floor to converge following the removal of the advancing, temporary longwall supports). The vertical displacement can vary along a fault step and may be accompanied by some degree of horizontal displacement. However, the size of step often appears to be consistent where the underground conditions are uniform. The extent of a step is very much limited directly to the magnitude of the area worked. Moreover, a single panel of small width-depth ratio approaching a fault at right angles is less likely to cause a step than a large width-depth ratio working parallel to a fault. A fault step is much more likely to develop when the fault has been affected by previous workings in the same mine, but stratigraphically above this horizon in shallow seams than it is for a single working in an unworked area. Once differential movement has been activated, 
then further movement in the immediate area can cause renewed movement along a fault, which at times may be out of proportion to the thickness and lateral extent of the coal extracted. The likelihood of fault reactivation increases with increasing number of seams worked and is associated more frequently with shallow workings (the uppermost seams nearest the ground surface). The cumulated effect of reactivation following multi-seam extraction may result in the generation of a large fault scarp in excess of $2 \mathrm{~m}$ in height.

The morphology, height and persistence of mining-induced fault scarps may be naturally influenced by the geotechnical properties of the surface materials and the geomorphology. For instance, fault scarps in the South Wales Coalfield have been observed to grow to more than $4 \mathrm{~m}$ in height and up to $4-5 \mathrm{~km}$ in length where thick sandstones crop out (Donnelly 2005; Donnelly et al., 2000a, 2000b). In addition, where a thin superficial cover is overlain by brittle engineered materials such as concrete surfaces or roads, then scarps tend to be distinctive, limited to single breaks, and may extend over hundreds of metres in length and be up to $2 \mathrm{~m}$ in height. However, the ground deformation on either side of the fault tends to be limited to a band of only a few metres. On the other hand, where weaker geologic ground exists, such as thick $(10 \mathrm{~m}+)$ ablation tills, sands and gravels or clay, then these may not support the formation and preservation of a fault scarp, or may simply allow temporary scarps to develop before erosion destroys them. In such instances a flexure develops, with a reduced amplitude, but affecting a much broader area on either side of the fault. What is more, in weak or unconsolidated soils the main fault slippage plane may become detached or splay into multiple semi-parallel fractures. Some faults have been observed in exploratory trenches to generate listric slip surfaces and intricate deformation structures (Figure 7). Layered parallel detachment may occur when the superficial deposits are stratified in an approximately horizontal fashion. This may lead to the generation of secondary faults that may branch out into a multitude of fractures or die out before reaching the original ground surface. The formation of graben structures are also a common surface expression of fault reactivation, especially where their traces occur on roads or concrete surfaces and the faults lie more or less parallel to the road alignment, or where lateral spreading has occurred in the aforementioned step-wise fashion (Donnelly et al, 2002).

Usually, horizontal displacements lateral shear only forms a component of ground movement at the outcrop of a fault. However, in some instances lateral shear displacements can dominate, with little or no vertical slip. Lateral shear tends to occur along faults when 
there is a significant change in strength of rock mass across the fault as, for instance, where a fault displaces sandstone against mudstone. It also is controlled by the geometrical relationships between mining and a fault (Donnelly and Reddish, 1993).

Compressional humps and heave may occur at fault outcrop positions during reactivation. According to Donnelly and Reddish (1993), some compressional humps are due to translational shear along bedding planes and joints. Humps remain as permanent features on the ground surface but may become degraded in time due to, for example, weathering and erosion, the ploughing of farmland or road repairs. In the USA however, compressional humps have been reported to be temporary in nature that generally arrives and passes as a wave form.

\section{Faults, ground movements and mine water rebound}

Field observations indicate that fault movements may occur during mining or after mining has ceased. The mining-contemporaneous movements along faults are associated with mining subsidence. Those movements that occur after mining has ceased may be associated with, for example, residual subsidence (see above), especially if it is significant, and mine water rebound. Unfortunately, it can be difficult or impossible to predict when the post-mining movements may occur. This can be of significance in Britain since insurance claims for mining subsidence compensation must be made within seven years of mining having taking place, according to the Subsidence Act 1994. The reason for this is that it is assumed, with traditional mining technical wisdom, that within seven years after the completion of mining most of the ground movement has taken place. Although this may seem to be reasonable, the authors have observed that such is not always the case, especially when faults occur within a subsidence trough.

Both a change in elevation and deformation of the ground surface has been observed in the vicinity of fault outcrops during, and several years after mining has occurred. In addition, groundwater emissions and release of gas emissions may be associated with faults that have undergone reactivation.

Underground mining generally has or had to overcome the problem of groundwaterinduced effects by dewatering the workings. Early mines in favourable locations utilized 
gravity drainage via tunnels (soughs) discharging into rivers or the sea, but it was the late $18^{\text {th }}$ century development of the steam engine that enabled large volumes of water to be pumped from mines. Frequently, deeper coal workings were made complexly interlinked, often from one colliery to another, to facilitate dewatering, access, ventilation, coal removal etc. Hence, it became necessary to maintain a network of pumping stations utilizing old shafts or boreholes in abandoned areas of a coalfield, in order to protect working collieries from flooding. It follows that the complete closure of a coalfield and cessation of pumping results in the ultimate flooding of most, if not all, the old workings with subsequent rebound of groundwater levels, at least until an overall hydrostatic equilibrium is reached. There is sufficient borehole monitoring and observation evidence to conclude that generally there is, at present, a general condition of regional recovery of the groundwater levels in the British coalfields. In this context, mine water may be regarded as water that has had contact with mine workings. Mine water frequently can be distinguished as water that is highly ferruginous (observed as orange-red ochrous deposist on stream beds) and often has a low $\mathrm{pH}$ value due to solution of pyrite oxidation products (Bell et al. 2002).

Groundwater and mine water rebound may increase the pore water pressures associated with faults, causing a reduction in shear strength of the material involved. This is capable of counteracting part of the normal stress acting across a fault and therefore may result in reactivation. It is the pore water pressure rather than the moisture content that influences fault stability. Pore water is practically incompressible and so counteracts the normal stress acting across a fault plane. If pore water confined within a fault zone cannot escape it will support (i.e. reduce) a part of the normal stress and reduce the stability of the material concerned (Hubbert \& Rubey 1959). Indeed, Sibson (1977) and Donnelly (1994) regarded fluctuating groundwater levels and elevated water pressures within fault zones as one of the most significant factors controlling both tectonic and mining induced fault reactivation.

As Britain is located on the relatively stable north-western European Platform it is generally regarded as a region of low seismicity and low tectonic deformation. There is no evidence to suggest that fault reactivation contemporaneous with mining subsidence and fault scarp generation in mining areas may have been caused by earthquakes and/or neotectonic processes. About 400 natural earthquakes occur each year in Britain, but these tend to be rarely perceived by persons, as they are recorded instrumentally, and occur deep within the basement, well beyond the upper $1000 \mathrm{~m}$ or so, where mining takes place. Although mining- 
induced seismicity occasionally occurs in Britain, this is likely to have been generated by the rock movements or failures resulting from changes in the state-of-stress in the rock mass in the vicinity of the mining excavation. These include; the collapse of the strong sandstone roof strata into goaf during longwall subsidence, bed separation or bed collapse, pillar failure in shallow abandoned room and pillar mines, and gas outbursts). Mining-induced seismicity generates small to moderate magnitude earthquakes (or tremors) and in the past decade UK coalfield events account for approximately 10 to 25\% of the earthquakes recorded annually by the British Geological Survey on the UK regional seismometer network.

Wilde \& Crook (1984) demonstrated the influence of elevated pore water pressures on fault stability. They were concerned about the effects of mining subsidence in the vicinity of the Winwick and Twenty Acre Faults, in the Warrington area of the Lancashire Coalfield, where major urbanisation redevelopment was planned. The Twenty Acre Fault was located to the east of the Winwick Fault and formed the eastern boundary of Bold Colliery. This provided an opportunity to investigate fault reactivation as it had been affected by mining subsidence. The superficial deposits consisted of weak alluvial soils and glacial lodgement till. A series of inclinometers and pneumatic piezometers were installed within these soils, and adjacent to the fault zone, to assess the pore water pressure variations prior to, during, and immediately following mining. In fact, the surface trace of the Twenty Acre Fault, gave rise to severe surface disruption, notably where it intersected the M62 motorway.

Up to two metres of subsidence occurred in the affected area, with a vertical differential component of movement across the fault of one metre. Strain measurements in excess of $50 \mathrm{~mm} \mathrm{~m}^{-1}$ were obtained from successive linear traverses between adjacent surface levelling stations across the fault. Inclinometers installed across the fault recorded a maximum lateral component of movement of $400 \mathrm{~mm}$. Piezometers installed across the fault not only showed excess pore water pressure in the clastic material occupying the fault zone but that, as undermining proceeded, pulses of very high pore water pressure occurred that were related to spasmodic subsidence movements. Hence, the fault was reactivating in an episodic manner rather than as a gradual process (Figure 8). On the other hand, because the fault accommodated most of the subsidence effects, the areas to the east of it were affected less than normally would have been the case. In this instance, the very large former aircraft hangars at the disused USAF Burtonwood Air Base, which were located only $150 \mathrm{~m}$ east of the fault, suffered relatively little from the effects of undermining. 
As mentioned above, changes in the elevation of the ground surface may occur in the vicinity of a fault trace. An increase in the elevation of the ground can be illustrated by what occurred in the Limburg Coalfield, The Netherlands. In 1974, the last working coal mine in the southern Limburg Coalfield was closed. This followed the discovery of natural gas resources in the 1960s in the southern North Sea, which marked the beginning of the end of coal production in The Netherlands. The phased abandonment of coal mines was associated with the cessation of mine water pumping, as many of the mine water pumps were switched off. The deeper mines became flooded first and this was associated with uplift at the ground surface. Following the ingress of mine water, an increase in pore water pressure occurred in the disturbed and heavily fractured rock mass above the collapsed longwall panels (Pottgens 1985). Under these conditions faults were accompanied by the generation of subsidence steps of up to $0.5 \mathrm{~m}$ at the ground surface. Generally, the uplift was observed as between 2 - $4 \%$ of maximum previously-detected vertical subsidence. Surveying observations showed ground movements occurring during mine water recovery in the vicinity of the Benzenrader, Heerlerheide and Feldbiss Faults (Bekendam \& Pottgens 1995 (Figure 9). These observations are consistent with similar observations made in British coalfields by Phillips \& Hellewell (1994) and Donnelly (1994).

Culshaw et al. (2006) observed uplift of the ground surface in part of the Staffordshire Coalfield around Stoke-on-Trent using satellite aperture synthetic radar (SAR) data processed using the permanent scatterer technique (PSInSAR) for the period 1992 to 2004. In the southern part of the coalfield, where mining did not end until 1998, ongoing subsidence was detected. Detectable uplift also was noted to have occurred in the northern part of the coalfield where mining had ceased much earlier. The uplift was attributed to a slower process of mine-water rise. Similar uplift was observed using PSInSAR data from the Durham Coalfield near Sunderland where mine water rise has been observed and modelled by Yu et al. (2006). Fault reactivation has been observed in both the Staffordshire Coalfield (at Barlaston, for example) and the Durham Coalfield (Houghton-le-Spring, Easington and many other locations). The PSInSAR observations confirm the general change in elevation of the ground surface post mining and it is suggested that the cause is mine-water rise, which also causes post-mining fault reactivation. Research is needed to identify how potential fault reactivation relates to areas experiencing ground level rise or areas of subsidence. 
The majority of the faults that have historically or recently (in the past 10 years) reactivated in the currently active and abandoned coal mining regions of Britain now appear to be stable. There, however, have been observations of continued or renewed ground movements in the vicinity of fault outcrops several years after mining has ceased (Donnelly \& Rees 2001; Donnelly 2000, 2006; Young \& Culshaw 2001; Yu et al. 2006). For example, investigations by Smith \& Colls (1996) at Swannington, in Leicestershire, provide examples of fault reactivation that occurred after mining ceased and yet were attributed to being caused by mine water rebound. In this instance, two scarps were observed to traverse a field. These were sub-parallel, $0.7 \mathrm{~m}$ high, trending NW to SE, and extended for a distance of $30-40 \mathrm{~m}$, in weathered Coal Measures mudstone. The scarps appeared developed over an 18 month period. One of the scarps was more distinct than the other and there was offset damage to a tiled field drain.

The Gelligaer Fault is a principal NW to SE trending fault in the South Wales Coalfield. Ground deformation monitoring was carried out in the late 1980s and early 1990s where the fault crosses the $1.2 \mathrm{~m}$ diameter, very high pressure Dowlais-to-Nelson natural gas main (Donnelly 1994). It was considered necessary to monitor the movement of the fault for ground rupture and strain accumulations as it was affected by subsidence during the longwall working of the Seven Feet Seam. Reactivation of the fault caused the generation of a scarp with associated high lateral hump-type compression. Indeed, Donnelly (2005) reported ground movements in the vicinity of the fault outcrop that were observed to continue for 10 years after mining finished. The mechanism(s) responsible for these ground movements are not fully understood but may be related to mine water rebound or associated fluctuations in groundwater levels, or both (Figure 10).

Barlaston is a small village located in north Staffordshire, in the Stoke-on-Trent and Newcastle-under-Lyme conurbation. From the 1960s to the middle of the 1990s numerous fault scarps were generated in the Barlaston region from longwall coal mining at Trentham (also known as Hem Heath) and Florence collieries. These movements were contemporaneous with mining but have continued after mining ceased. The cumulative length of the various parallel fault scarps was at least $50 \mathrm{~km}$, with individual fault scarps reaching 2 $\mathrm{m}$ in height and several hundreds of metres in length. Numerous faults were detected and monitored, and their reactivation recorded as they were affected by the passing wave of mining subsidence. The consequences of fault reactivation were severe and often dramatic, 
both in terms of financial and insurance losses, and damage to houses, commercial and industrial buildings, roads, utilities, churches, bridges and agricultural land (Donnelly \& Rees 2001). It was noted that the active fault scarps provided hydraulically conductive subsurface channelways for groundwater flow. Abundant seeps, springs and debris cones regularly were observed on the downthrown side of such faults, caused by discharge of groundwater gathered during reactivation. As mentioned, ground movements, albeit more subtle, as well as groundwater discharges have continued, at a much reduced rate, for over 15 years since mining ceased. The groundwater discharges have resulted in localized flooding of agricultural land and house foundations (Figure11), rising, discharging, and then channelled mainly into subsidence troughs and depressions, or accumulating on the downthrown side of reactivated fault scarps.

The origin and pathways of the groundwater within the Barlaston subsidence faults are not known. They, however, are not thought to represent mine water, but are likely to represent the re-emergence of meteoric waters, flowing within the superficial deposits and near surface Coal Measures sandstones. Alternatively, meteoric waters are thought to migrate downwards along the subsidence-affected faults, and join with the mine-area ground water. Groundwater levels at the two main collieries in the region (Trentham and Florence, both now closed and demolished) were controlled by upward pumping and surface discharge. However, should pumping be stopped or the pumping rate reduced, then this will allow mine water levels to rebound. Under such circumstances the major principal faults across the region may be potentially susceptible to further phases of reactivation.

At Easington, County Durham, the generation of graben and fault scarps, over $300 \mathrm{~m}$ long, caused severe and widespread damage to rows of terraced houses and roads (Donnelly 1998). These were occasionally accompanied by small-magnitude, non-seismic earth tremors according to local residents. The graben and fault scarps appeared along the ground surface many years after mining finished at the former Easington Colliery. The graben was attributed to the dilation of fissures and reactivation of faults in the underlying bedrock of strong, welljointed Lower Magnesian Limestone of Permian age. This consists of an upper, 20 - $70 \mathrm{~m}$ thick, strong, bedded dolomite that overlies the Marl Slate, a strong, laminated dolomitic siltstone of varying thickness. The Marl Slate, in turn, overlies the weak and partially cemented Basal Permian Sands, located unconformably above the Coal Measures that have been extensively mined. The post-mining ground movements along the faults and fissures 
were attributed to mine-water rebound. In the Durham Coalfield 300 years of groundwater pumping had dewatered the strata by depths of up to $150 \mathrm{~m}$ and rebound is now taking place (Younger \& Bradley 1994; Yu et al. 2007). If the new groundwater level intersects faults that contain subsidence strain accumulations, then post-mining fault reactivation is possible (Figure 12).

Fracturing in the carriageway of the A690 Sunderland to Durham road at Houghton-leSpring road cutting, in limestones of the Raisby Formation (Permian), which were associated with post-mining fault reactivation, were reported in local newspapers in 2001. This and subsequent investigations drew public attention to the possible implications for potential contaminant transport from waste disposed in the Houghton Quarry landfill site, which lies close to the damaged road (Donnelly 1998; Young \& Culshaw 2001; Wigham 2000). Many other fissures were observed in the region, reported by Donnelly (2006). Some of the fissures extended for a strike distance of at least $1 \mathrm{~km}$ and were associated with crown holes (caused by the collapse of bridging soil cover and vegetation). Investigations again showed that the reactivation of the faults may be attributed to mine water rebound (Yu et al. 2006).

\section{Some effects of fault reactivation on land use planning and ground engineering}

Post-mining fault reactivation can cause significant planning and engineering problems particularly where such features intersect linear infrastructure and light buildings and structures. The following are particularly vulnerable:

- linear structures such as roads, railways and pipelines;

- buildings with shallow foundations, particularly houses;

- agricultural land through disruption to drainage, injury to livestock falling into crown holes and fissures and disruption to mechanical farming;

- leakage from reservoirs and waste disposal sites;

- steeper natural slopes, opencast pit walls, embankments and cuttings.

To reduce the risks, site investigation should be designed to address three specific questions: 
- Is fault reactivation likely to occur in the area under investigation within the design lifetime of the proposed building or structure?

- Which fault or faults may be affected by fault reactivation?

- What are the spatial locations of these faults?

As has been indicated, the areas that are likely to be affected by fault reactivation have been identified for the UK, in particular, (Donnelly 2006) and elsewhere. Such reactivation is associated with areas in which mining has been abandoned and where mine water levels are rising. Such areas are often still experiencing ground level change, either subsidence or ground level rise, both of which can be identified by either ground surveying or satellite radar interferometry.

Once it has been determined that an area might be susceptible to residual fault reactivation, individual susceptible faults must be identified. These will then need careful investigation to identify their exact location. This will require a specific desk study involving large scale geological maps, mine plans and, possibly, local information in the media on previous ground movements. From these, likely fault traces at the ground surface should be estimated. These can then be investigated by large scale mapping (at 1:10,000 scale or greater) to identify displaced kerbs, cracks in roads and buildings, crown holes (either open or infilled), topographic 'steps' in the ground surface and any other evidence of recent ground movement (Young \& Culshaw 2001). Local landowners may be a useful source of information on deformation, even if they do not recognise the cause of any features. The results of the desk study and the mapping should be used to delineate the fault traces more accurately. Ground investigation then will be needed. Dependant on the particular ground conditions, this might involve geophysical methods and/or exploratory trenching across the surface trace of the fault. Where linear structures and services must traverse susceptible faults, they should be placed at right angles and with operational design features to accommodate anticipated movements.

From a land-use planning point of view, it is desirable to identify a lateral zone of exclusion around traces faults that may reactivate, or at least make special planning conditions attached to any permission. Obviously, building over faults in areas likely to be subjected to subsidence should be avoided wherever possible because of the relatively uncertain nature of 
any associated surface ground movements and the fact that structures normally cannot be designed to withstand highly localized and attenuated differential subsidence. It has long been an empirical rule of Civil Engineers that differential vertical ground displacements of more than $12 \mathrm{~mm}$ in $13 \mathrm{~m}$ borders on a condition leading to structural damage. However, whilst subsidence damage to structures located close to, or on, the surface outcrop of a fault can be very severe (sometimes so severe that buildings have to be demolished), the areal extent of such damage is limited, often being confined to within a few linear metres of the outcrop (Figure 4). Anon (1959) and Donnelly (1994) recommended that structures be set back at least $16 \mathrm{~m}$ and $10 \mathrm{~m}$ respectively from the line of surface outcrop of a fault. This suggests that a buffer zone of around 15 - 20 m on each side of a fault trace may be necessary in vulnerable areas. Such planning controls would not need to be in place indefinitely, as post mining fault reactivation seems to be time limited.

\section{Conclusions}

The total extraction of coal, in unfaulted ground, by longwall mining, results in subsidence of the ground surface. This occurs virtually contemporaneously with mining, due to the almost instantaneous transmission of strains to the ground surface, to generate a subsidence trough. The time taken for subsidence to be completed is approximately inversely proportional to the rate of forward advance of the workings. For all practical purposes, subsidence is complete when the face has advanced 0.75d (where $d$ is the depth of the workings) beyond a given point on the ground surface, residual subsidence then occurs. Residual subsidence rarely exceeds $10 \%$ of total subsidence and is usually complete within two years, with some instances taking six to seven years, and a few recorded cases taking 11 years.

When coal is extracted in the vicinity of faults, they may undergo reactivation (although this is not always the case). This generates scarps, grabens, fissures or compression humps at the ground surface. Some faults scarps are subtle but many are distinct striking features. The consequences of fault reactivation may be widespread damage to land and existing structures. Fault reactivation and residual ground movements also may present a significant risk to new construction, planning and redevelopment. 
Ground movements in the vicinity of reactivated faults tend to occur and continue in increasing magnitude for longer periods of time than the 'normal' residual subsidence window of approximately two to seven years. The magnitudes of the residual ground movements along faults are relatively small and are observed as increases in the height of the ground (sometimes called upsidence); increases in the height of fault scarps (caused by shear displacements and settlement along one side of the fault plane); exacerbation of wave-like compression humps and dilation of fissures. Increases in ground elevation may be caused by groundwater rebound and elevated pore water pressures within and adjacent to faults.

The duration of post-mining ground movements is not currently possible to predict due to the lack of observational data. Fault scarps tend to be quickly repaired in the UK, because they present a risk to traffic, land may be required for development and construction, or scarps may be damaged by ploughing of agricultural land. This has prevented almost all proper monitoring of post-mining ground movement at fault outcrops. However, examples from South Wales, the Midlands and Durham coalfields tend to suggest that post-mining ground movements along and around reactivated tectonic faults may continue for about 15 years after mining has finished. This equates to an increase of over $100 \%$, when compared to residual ground movements recorded during subsidence in unfaulted ground (which, as mentioned, may be up to 6 or 7 years). It is not known if the few cases of residual subsidence at fault outcrops are representative of the duration of complete post-mining induced fault reactivation.

The cause of post-mining induced fault reactivation (in longwall-mined coal fields) is not fully understood, but is thought to be related primarily to groundwater flows and mine water rebound, caused by the cessation of mine water pumping schemes. These were required historically to suppress regional groundwater levels in the British coalfields, as a necessary feature of all forms of coal mining, from the $18^{\text {th }}$ through $20^{\text {th }}$ centuries.

It is recommended that faults that have historically, or recently been reactivated during mining subsidence, should be avoided as far as the siting of structures, houses, buildings, landfill, roads and utilities are concerned. If fault outcrop positions cannot be avoided, then a properly designed site investigation should be undertaken to obtain information on the geology, geomorphology, structural geology, hydrogeology, past mining, and the geotechnical properties and engineering behaviour of the ground. Such an investigation should aim to 
provide information that will allow a degree of engineered flexibility in design, to accommodate the ground conditions and/or to undertake appropriate ground treatment mitigative measures. This investigation should also consider the possibility of gas emissions, groundwater and mine water discharges, reduced bearing capacity and collapse-prone voids within the fault zone.

Most faults that have reactivated during mining subsidence in Britain are now grown stable due to the long-term dissipation of ground strains and decline in deep longwall mining. Postmining ground movements may continue to take place on some of the principal faults that define greater structural geologic blocks in the Coal Measures. It is not currently possible, however, to predict the timing and magnitude of such ground movements, or associated gas and/or groundwater (or mine water) emissions.

Acknowledgements. This paper is published with the permission of the Executive Director of the British Geological Survey (NERC) and Halcrow Group Limited.

\section{References}

ANON. 1959. Report on Mining Subsidence. Institution of Civil Engineers, London.

ANON. 1975. Subsidence Engineers Handbook. National Coal Board, London.

BEKENDAM, R. F. \& PÖTTGENS, J. J. E. 1995. Ground movements over the coal mines in southern Limberg, The Netherlands, and their relation to rising mine waters. Proceedings of the $5^{\text {th }}$ International Symposium on Land Subsidence, the Hague, October 1995, IAHS, No. 234, 3-12.

BELL, F. G. \& DONNELLY, L. J. 2006. Mining and its Impact on the Environment. Spon Press, London.

BELL, F.G., HALBICH, T.F.J. \& BULLOCK, S.E.T. 2002. The effects of acid mine drainage from an old mine in the Witbank Coalfield, South Africa. Quarterly Journal of Engineering Geology and Hydrogeology, 35, 265-278.

CULSHAW, M. G., McCANN, D. M. \& DONNELLY, L. J. 2000. The impact of abandoned mineworkings on aspects of urban development. The impact of abandoned mineworkings on aspects of urban development. Transactions of the Institution of Mining and Metallurgy, Section A, 109, A132-A139.

CUlShAW M. G., TRAGHEIM, D., BATESON, A \& DONNELLY, L. J. 2006. Measurement of ground movements in Stoke-on-Trent (UK) using radar interferometry. 
In: CULSHAW, M. G., REEVES, H., JEFFERSON, I. \& SPINK, T. (eds), “The Engineering Geology for Tomorrows Cities," Proceedings of the $10^{\text {th }}$ Congress of the International Association for Engineering Geology and the Environment, Nottingham, UK, 6-10 September 2006. On CD-Rom, Geological Society, London.

DONNELLY L. J. 1994. Predicting the Reactivation of Geological Faults and Rock Mass Discontinuities during Mineral Exploitation, Mining Subsidence and Geotechnical Engineering. Ph.D. Thesis, University of Nottingham.

DONNELLY, L. J. 1998. Fault Reactivation and Ground Deformation Investigation, Easington Colliery, County Durham. British Geological Survey Technical Report WN/98/9.

DONNELLY, L. J. 2000. The reactivation of geological faults during mining subsidence from 1859 to 2000 and beyond. Transactions of the Institution of Mining and Metallurgy, Section A, 109, A179-A190.

DONNELLY, L. J. 2005. Fault reactivation in South Wales and the affects on ground stability. In: NICHOL, D., BASSETT, M. G. \& DEISLER, V. K. (eds), The Urban Geology of Wales. National Museum of Wales Geological Series No. 24, Cardiff, 101119.

DONNELLY, L. J. 2006. A review of coal mining-induced fault reactivation in Great Britain. Quarterly Journal of Engineering Geology \& Hydrogeology, 39, 5-50.

DONNELLY L. J. \& REDDISH, D. J., 1993. The development of surface steps during mining subsidence: not due to fault reactivation. Engineering Geology, 36, 243-255.

DONNELLY, L. J. \& REES, J. 2001. Tectonic and mining-induced fault reactivation around Barlaston on the Midlands microcraton. Quarterly Journal of Engineering Geology and Hydrogeology, 34, 195-214.

DONNELLY, L. J., NORTHMORE, K. J., \& JERMY, C. A. 2000a. Fault reactivation in the vicinity of landslides in the South Wales Coalfield. In: BROMHEAD, E., DIXON, N. \& IBSEN, M. L. (eds). Landslides in research, theory and practise, Proceedings of the $8^{\text {th }}$ International Symposium on Landslides, Cardiff, Wales, 26-30 June. 481-486.

DONNELLY, L. J., NORTHMORE, K. J \& SIDDLE, H. J. 2000b. Lateral spreading of moorland in South Wales. In: SIDDLE, H. J., BROMHEAD, E. N. \& BASSETT, M. G. (eds). Landslides and Landslide Management in South Wales. National Museum \& Galleries of Wales, Geological Series No. 18, Cardiff, June, 43-48. 
DONNELLY, L. J., NORTHMORE, K. J \& SIDDLE, H. J. 2002. Block movements in the Pennines and South Wales and their association with landslides. Quarterly Journal of Engineering Geology and Hydrogeology, 35, 33-39.

FERRARI, C.R. 1997. Residual coal mining subsidence - some facts. Mining Technology, 79, 177-183.

HELLEWELL, E. G. 1988. The influence of faulting on ground movements due to coal mining. The UK and European experience. Mining Engineer, 147, 334-337.

HUBBERT, M. K. \& RUBEY W. W. 1959. The role of fluid pressure in the mechanics of overthrust faulting. Bulletin of the Geological Society of America, 70, 115-166.

LEE, A. J. 1965. The effects of faulting on mining subsidence. MSc. Dissertation, University of Nottingham.

PHILLIPS, K. A. S. \& HELLEWELL, E. G. 1994. Three-dimensional ground movements in the vicinity of a mining activated geological fault. Quarterly Journal of Engineering Geology, 27, 7-14.

PÖTTGENS, J. J. E. 1985. Uplift as a result of rising mine waters. In: The Development Science and Art of Minerals Surveying, Proceedings of the $6^{\text {th }}$ International Congress. International Society for Mine Surveying, Harrogate (UK), 2, 928-938.

SIBSON, R. H. 1977. Fault rocks and fault mechanics. Journal of the Geological Society of London, 133, 191-214.

SINGH, K.B. \& SINGH, T.N. 1998. Ground movements over longwall workings in the Kamptee Coalfield, India. Engineering Geology, 50, 125-139.

SMITH, J. A. \& COLLS, J. J. 1996. Groundwater rebound in the Leicestershire Coalfield. Journal of the Chartered Institution of Water and Environmental Management, 10, 280289.

WARDELL, K. 1954. Some observations on the relationship between time and mining subsidence. Transactions of the Institution of Mining Engineers, 113, 471-483 and 799814.

WHITTAKER, B. N. \& REDDISH, D. J. 1989. Subsidence: Occurrence, Prediction and Control. Elsevier, Amsterdam.

WIGHAM, D. 2000. Occurrence of mining-induced open fissures and shear walls in the Permian limestones of County Durham. Transactions Institution Mining Metallurgy, Section A, Mining Technology, 109, A131-A244.

WILDE, P. M. \& CROOK, J. M. 1984. The significance of abnormal ground movements due to deep coal mining and their effects on large scale surface developments at Warrington 
New Town. Proceedings of a Conference on Ground Movements and Structures, Cardiff, UK, GEDDES J. (Ed),. Pentech Press, London, 240-247.

YAO, X.L. \& REDDISH, D. J. 1994. Analysis of residual subsidence movements in U.K. coalfields. Quarterly Journal Engineering Geology, 27, 15-23.

YOUNG, B. \& CULSHAW, M. G. 2001. Fissuring and Related Ground Movements in the Magnesian Limestone and Coal Measures of the Houghton-le-Spring Area, City of Sunderland. British Geological Survey Technical Report WA/01/04.

YOUNGER, P. L. \& BRADLEY, K. F. 1994. Application of geochemical mineral exploration techniques to the cataloguing of problematic discharges from abandoned mines in northeast England. In: Proceedings of the 5th International Minewater Congress, Nottingham, UK, 2, 857-871.

YU, M-H., JEFFERSON, I. \& CULSHAW, M. G. 2006. Geohazards caused by rising groundwater in the Durham Coalfield, United Kingdom. In: CULSHAW, M. G., REEVES, H., JEFFERSON, I. \& SPINK, T. (eds), “The Engineering Geology for Tomorrows Cities," Proceedings of the $10^{\text {th }}$ Congress of the International Association for Engineering Geology and the Environment, Nottingham, UK, 6-10 September 2006. On CD-Rom, Geological Society, London.

YU, M-H., JEFFERSON, I. \& CULSHAW, M. G. 2007. Fault reactivation, an example of environmental impacts of groundwater rising on urban area due to previous mining activities. In: Proceedings of the $11^{\text {th }}$ Congress of the International Society for Rock Mechanics, Lisbon, 9-13 July 2007 (in press). 
LONGWALL MINING-INDUCED FAULT REACTIVATION AND DELAYED SUBSIDENCE GROUND MOVEMENT IN BRITISH COALFIELDS

Laurance J Donnelly ${ }^{1}$, Martin G Culshaw ${ }^{2}$ and Fred G Bell ${ }^{2}$

Figures 


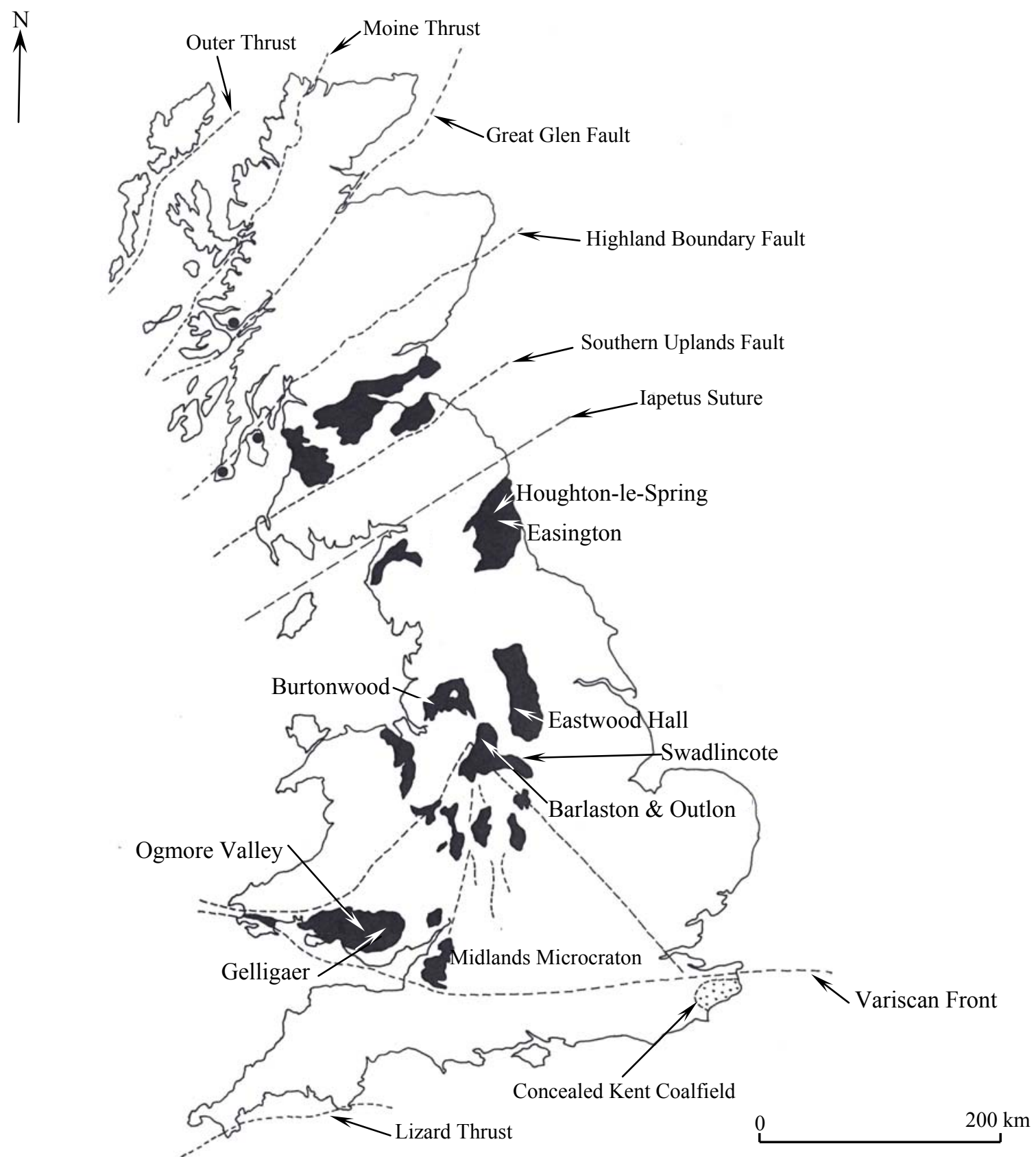

Figure 1. Map to show the location of coalfields in the UK, major tectonic structures and places mentioned in the paper. 
A

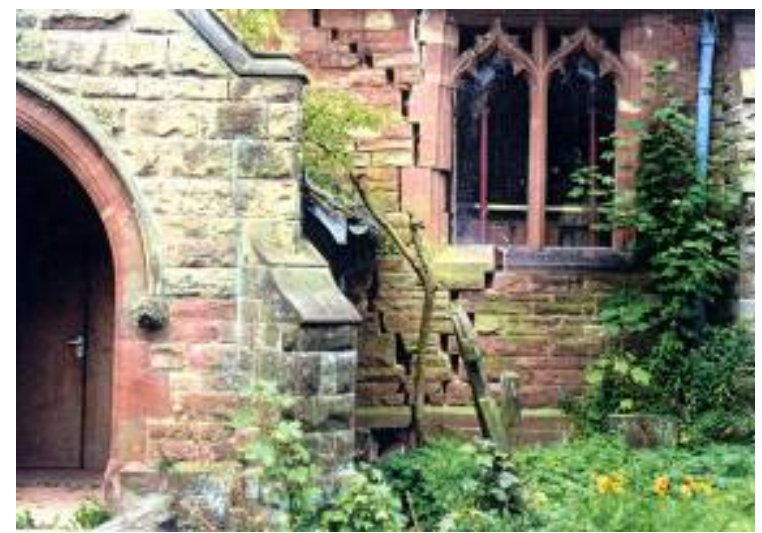

$\mathrm{C}$

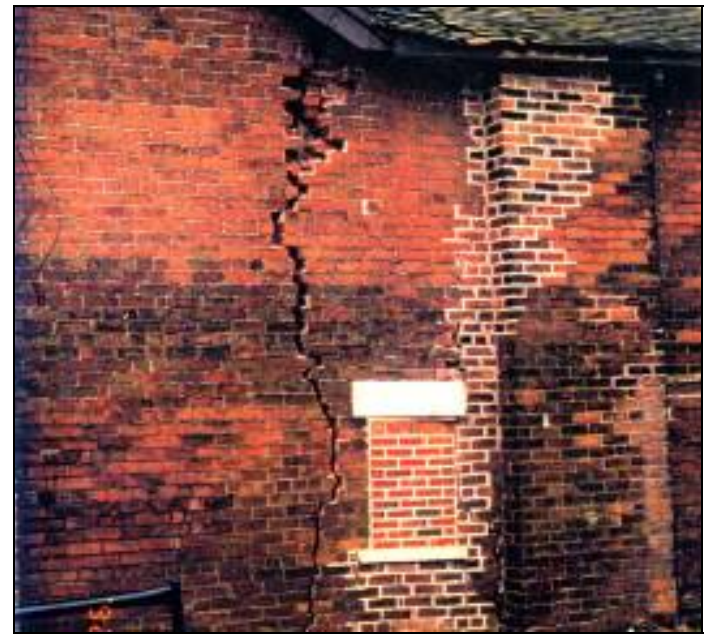

B

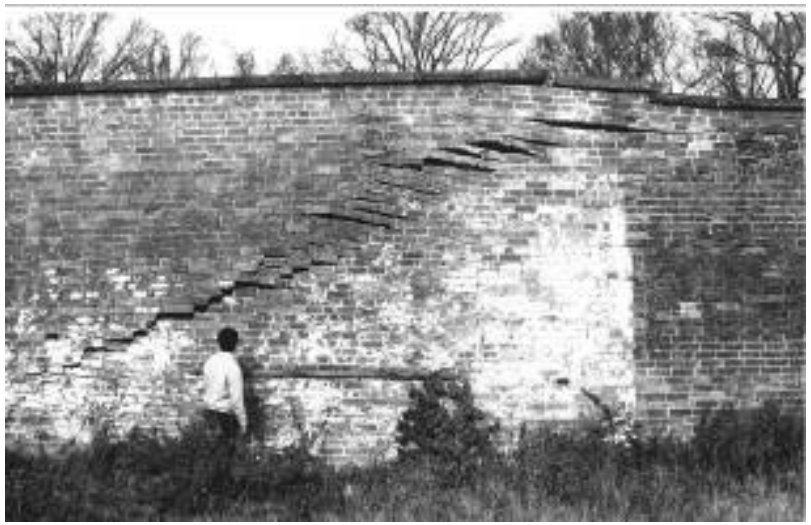

$\mathrm{D}$

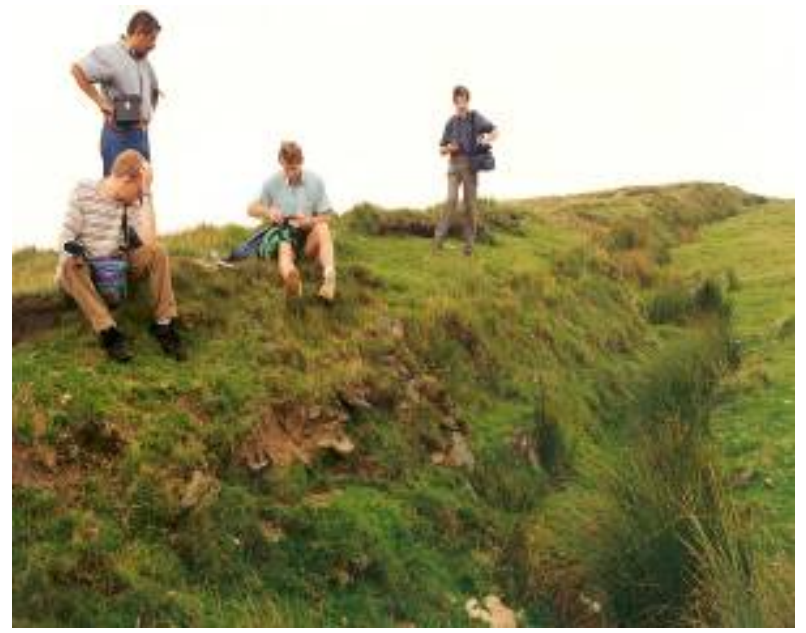

Figure 2 The results of fault reactivation contemporaneous with mining and subsidence. (A) Severe damage to Barlaston Church, Staffordshire. (B) Compression along a fault, Eastwood Hall, Nottinghamshire. (C) A house built on the outcrop of the Hopton Fault, Oulton, Staffordshire. (D) The $4 \mathrm{~m}$ high and $4 \mathrm{~km}$ long, Tableland Fault scarp wall, at the head of the Ogwr Valley, South Wales. This fault scarp was likely to have originally been generated by deglaciation and stress relief of valley sides in the closing stages of the Pleistocene 'Ice Age' and subsequently exacerbated by mining subsidence over centuries of coal mining (after Donnelly 1994). 


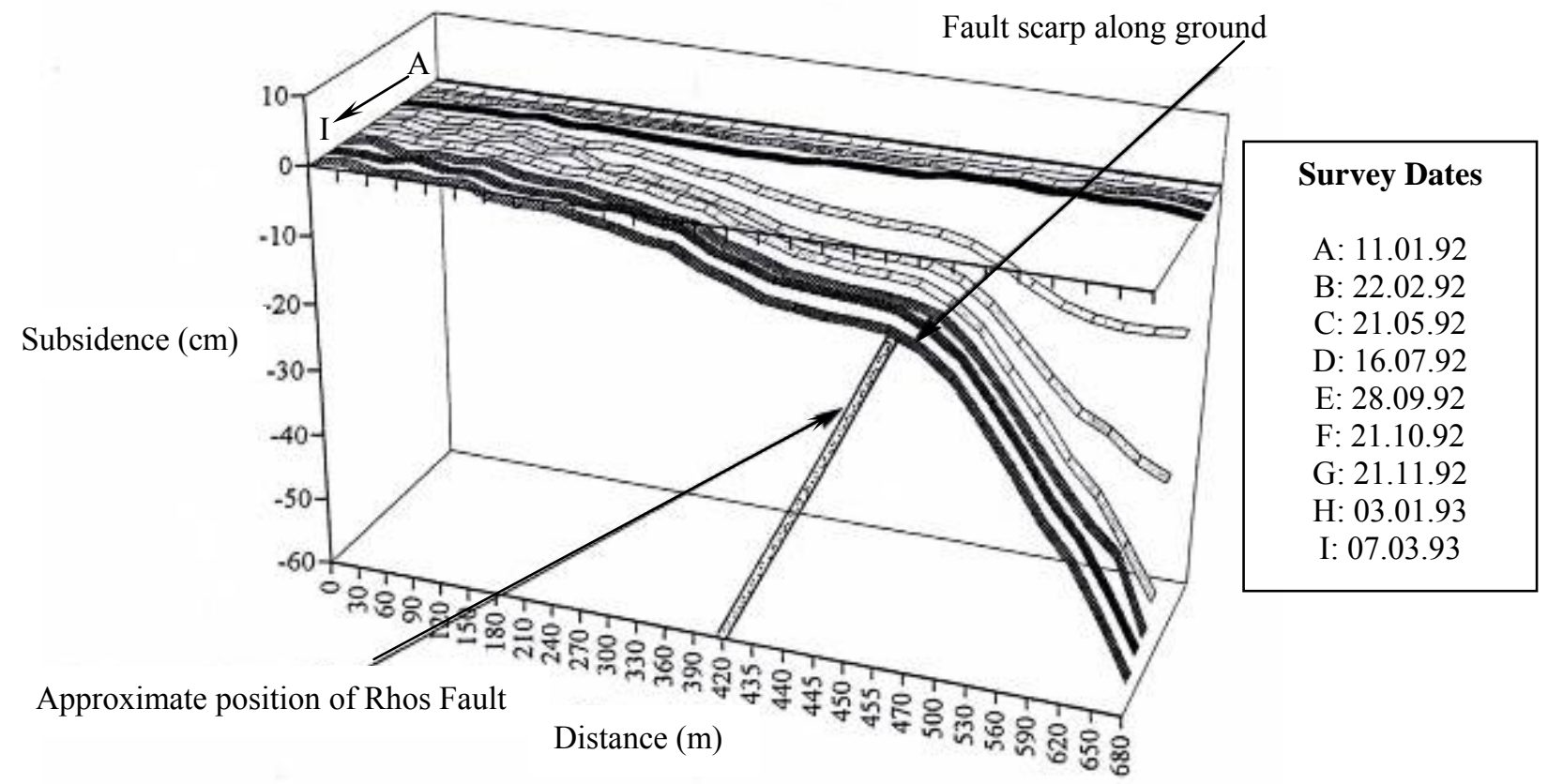

Figure 3 Typical subsidence profile showing the reactivation of the Rhos Fault contemporaneous with mining subsidence, during the longwall extraction of coal seam from a heading at Taff Merthyr Colliery. Ground movements were monitored using precise levelling from a fixed point located at position 0 on the x-axis (after Donnelly 1994). 

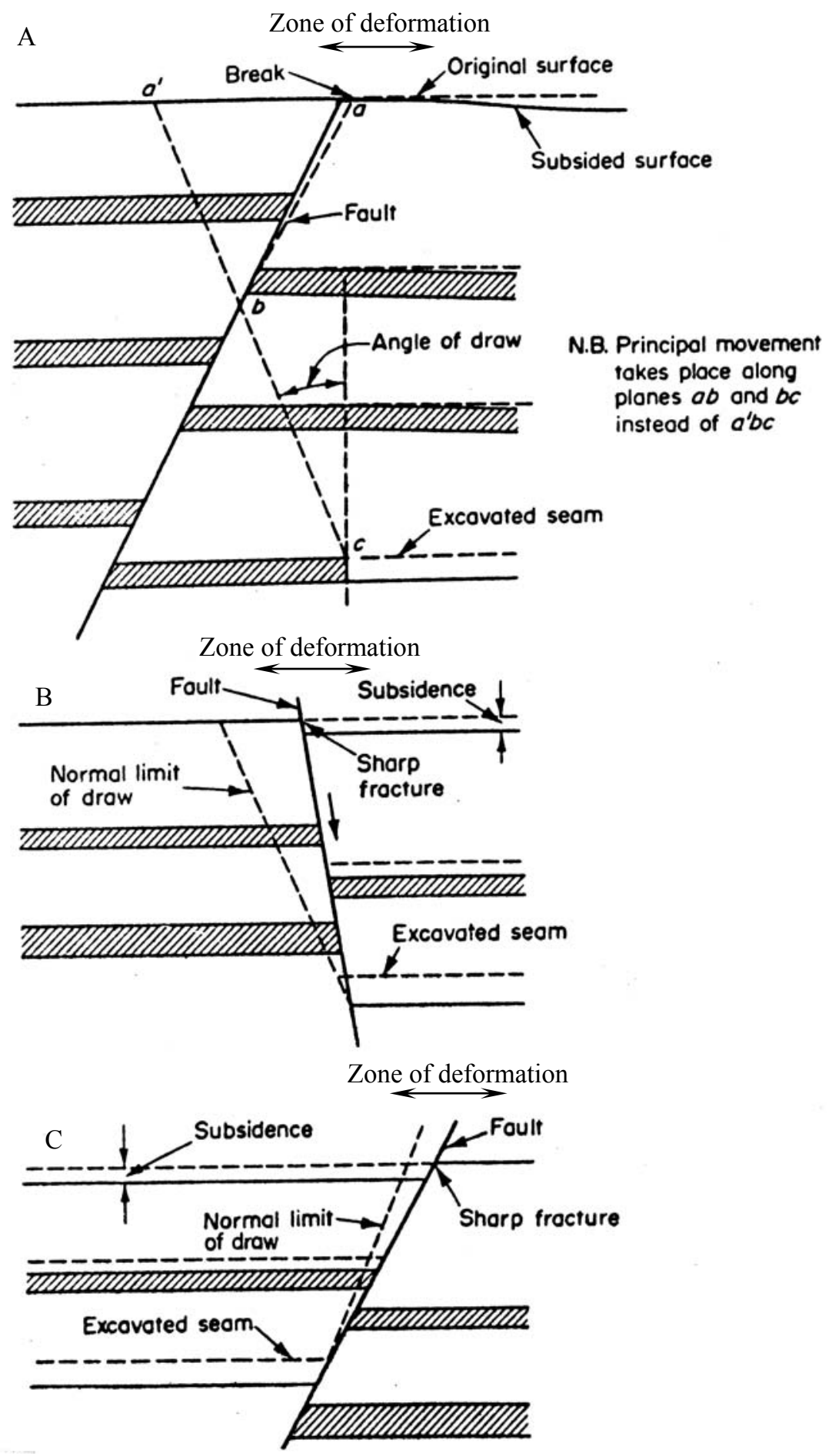

Figure 4 Schematic, conceptual illustration (not to scale) to show the zone of ground deformation around the outcrop positions of faults. The directions of strike of the faults are oriented approximately parallel to the advancing longwall panel extraction face. (A) Extraction in the footwall of a fault. (B) Extraction in the hangingwall of a fault. (C) Extraction in the hangingwall of a low angled fault (dipping less than about $70^{\circ}$ ) (modified after Bell \& Donnelly 2006). 


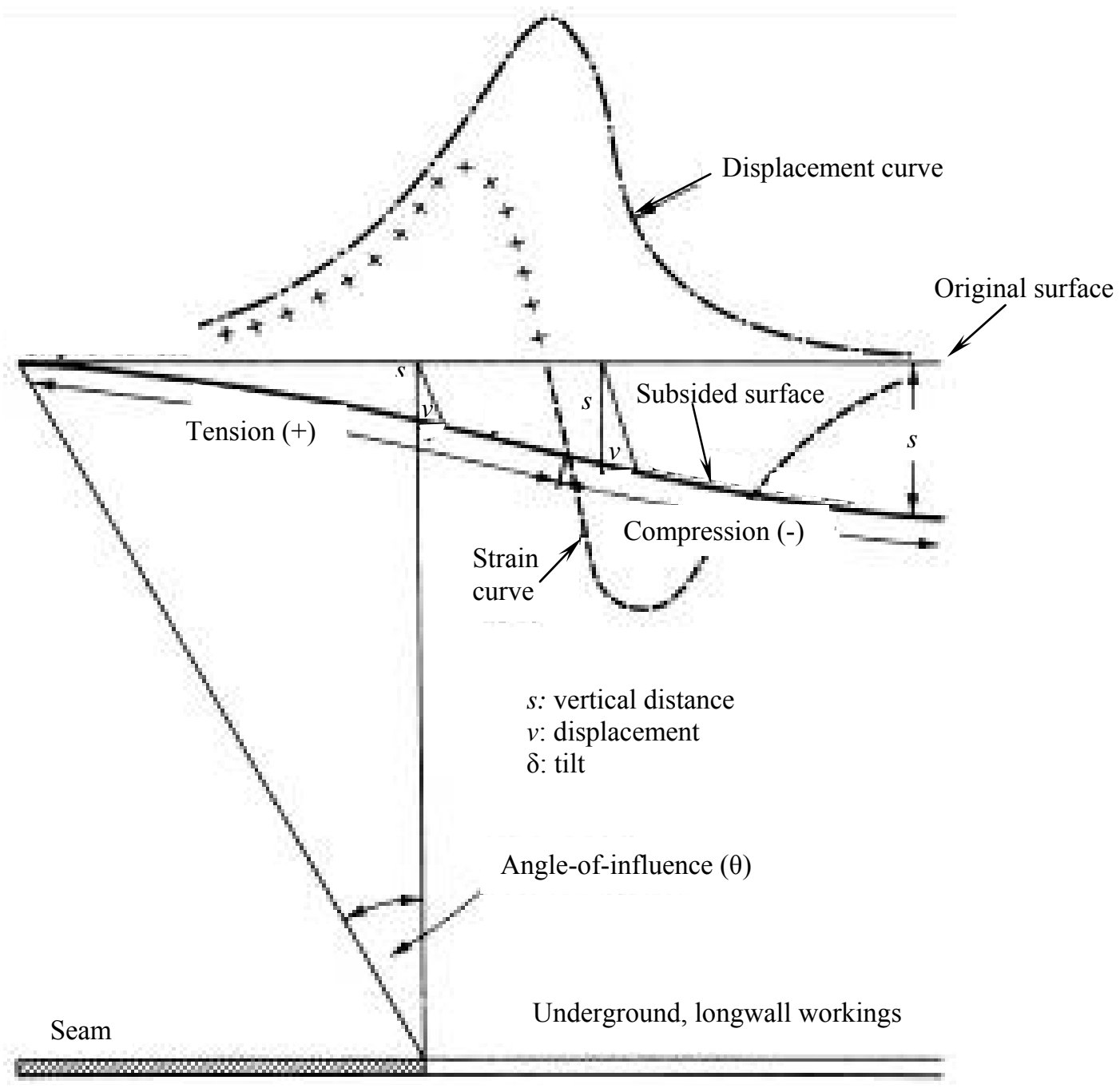

Figure 5 Typical subsidence curve showing compressive and tensile strains, vertical subsidence, tilt and angle-of-draw (known also as the angle-of-influence). The displacement and strain curves represent a fixed period of time, as the passing 'wave' of subsidence incrementally changes the magnitude of vertical displacement associated with longwallinduced coal mining subsidence. 

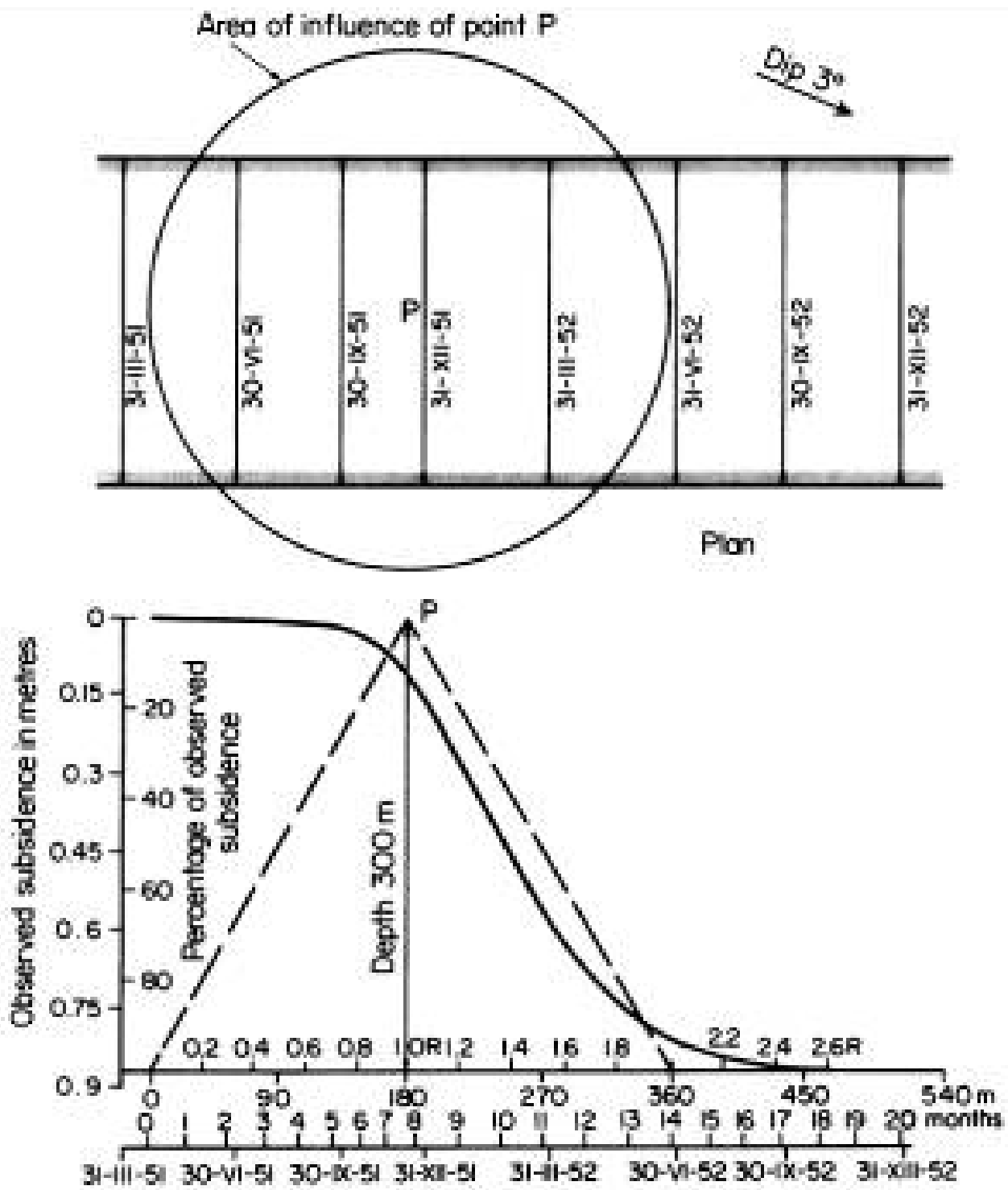

Figure 6 Relationship between subsidence and time and residual subsidence (modified after Wardell 1954). 
A

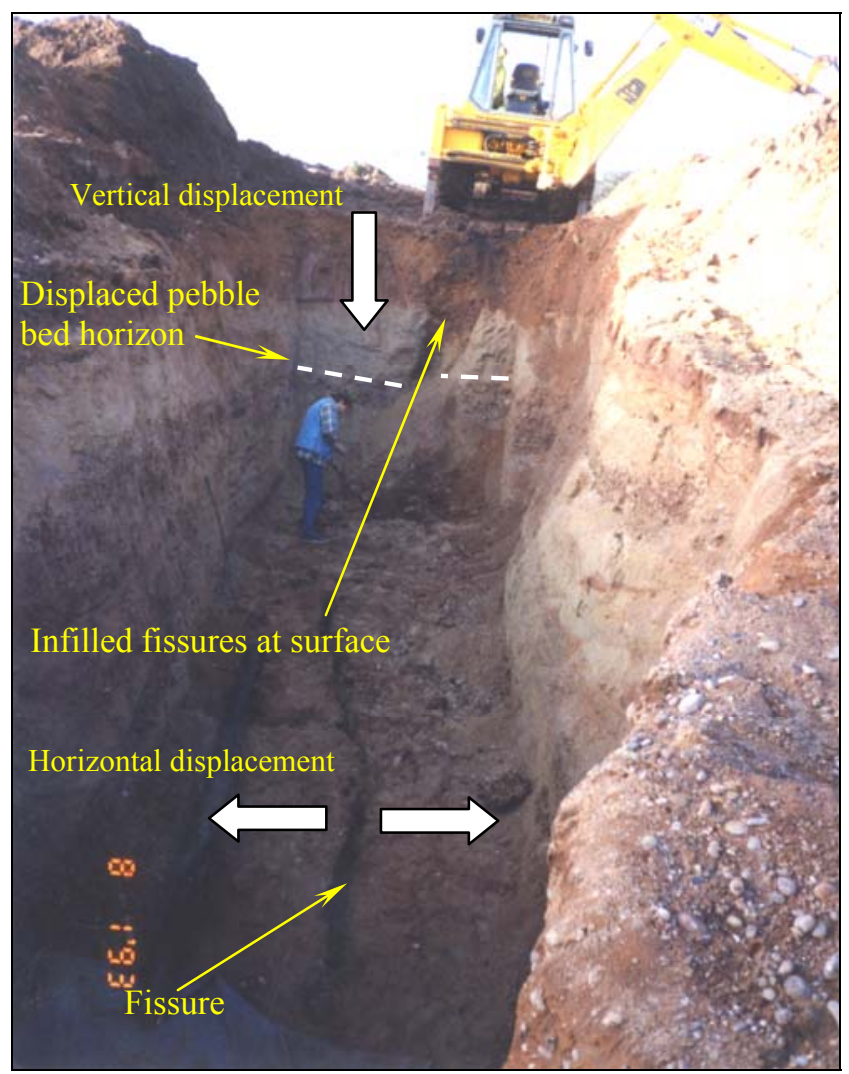

$\mathrm{B}$

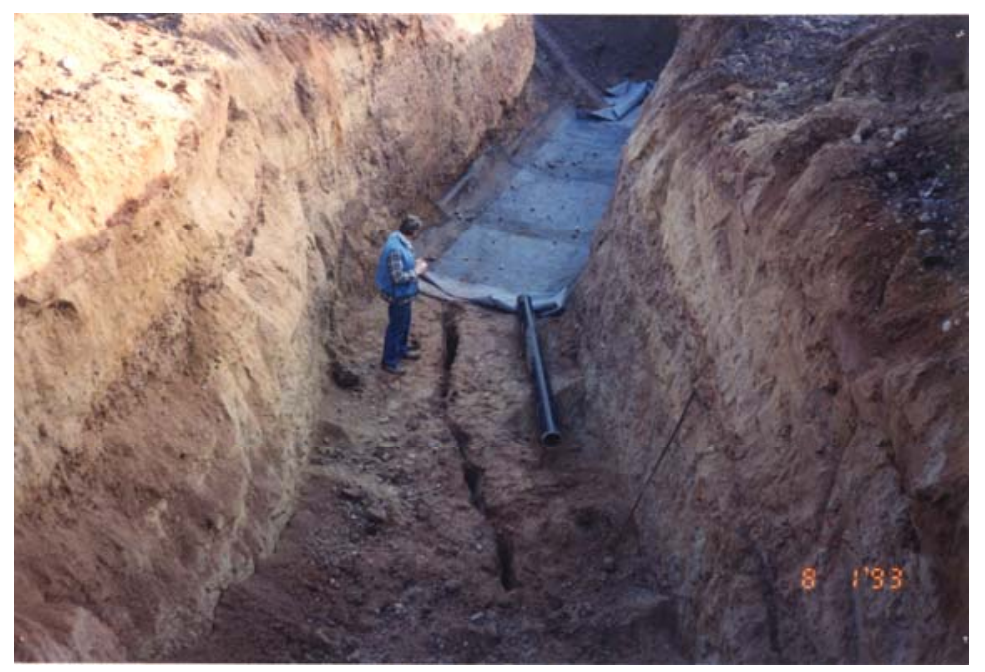

Figure 7. Faults that have reactivated contemporaneous with mining, seen exposed in an inspection trench. (A) The fault plane is clearly visible having displaced the superficial deposits and dilated the plane to produce a fissure, up to $1 \mathrm{~m}$ wide and several hundreds of metres long. The back wall of the exploratory trench shows the horizontal displacement of the fault plane, which was subsequently infilled with red-brown granular soil and vertical displacement of a pebble bed horizon in the Sherwood Sandstone Formation. (B) Geotextile grids were deployed to mitigate against further movements along the fault, Downes Bank, Oulton, Staffordshire (after Donnelly 1994). 

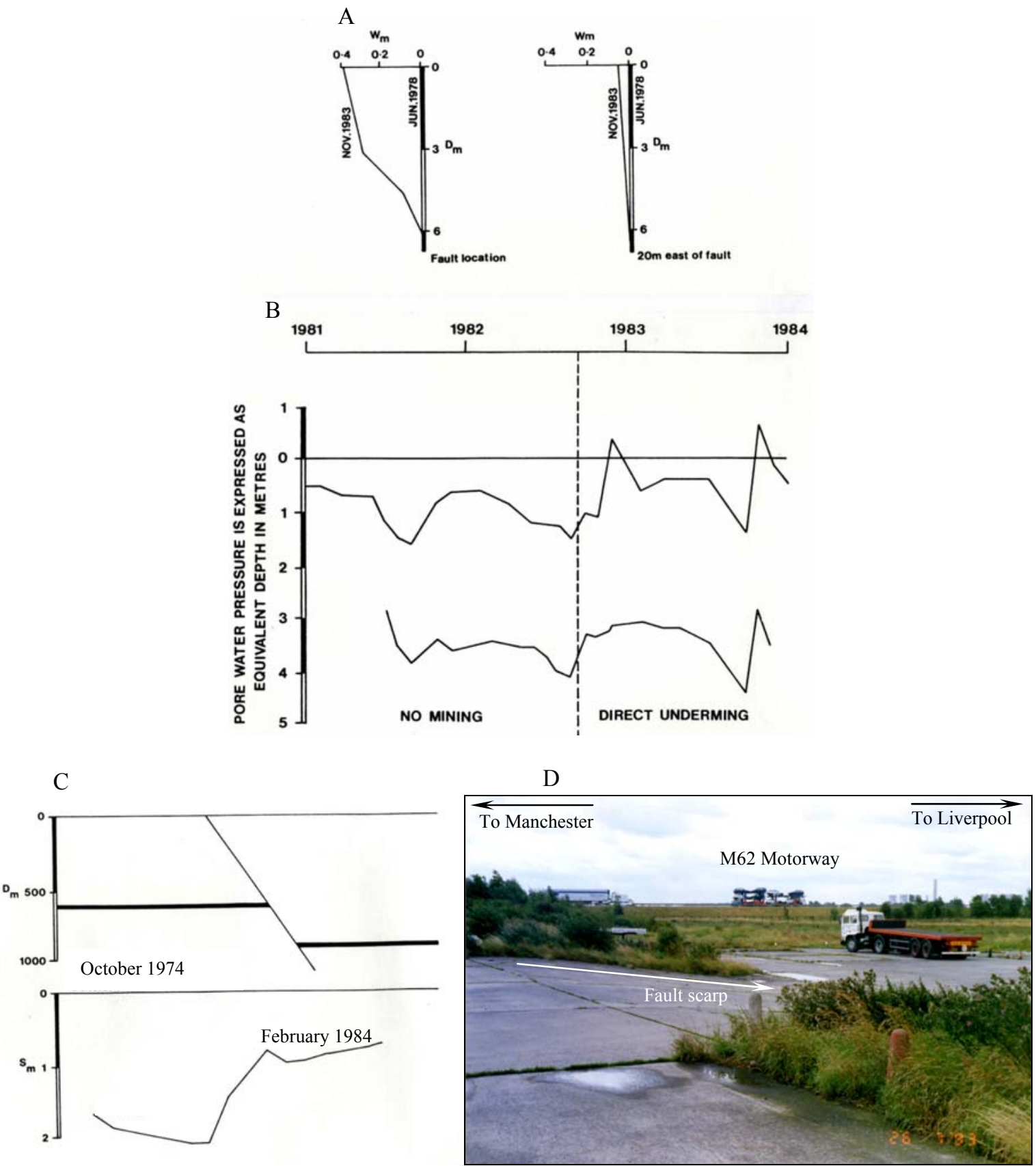

Figure 8 (A \& B) Results from pneumatic piezometers and inclinometers installed in the Twenty Acre fault zone, recording elevated pore fluid pressures associated with reactivation. (C) Subsidence profile across the twenty acre fault, where it outcropped along the USAF Burtonwood Air Base runway (now disused). (D) Photographs showing the generation of a fault scarp, $1.5 \mathrm{~m}$ high across part of the airfield runway. This also caused severe damage to the M62 motorway (seen in background) resulting in repairs to the carriageway and traffic delays, Lancashire, (data has been modified after Wilde and Crook 1984 and Donnelly 1994). 

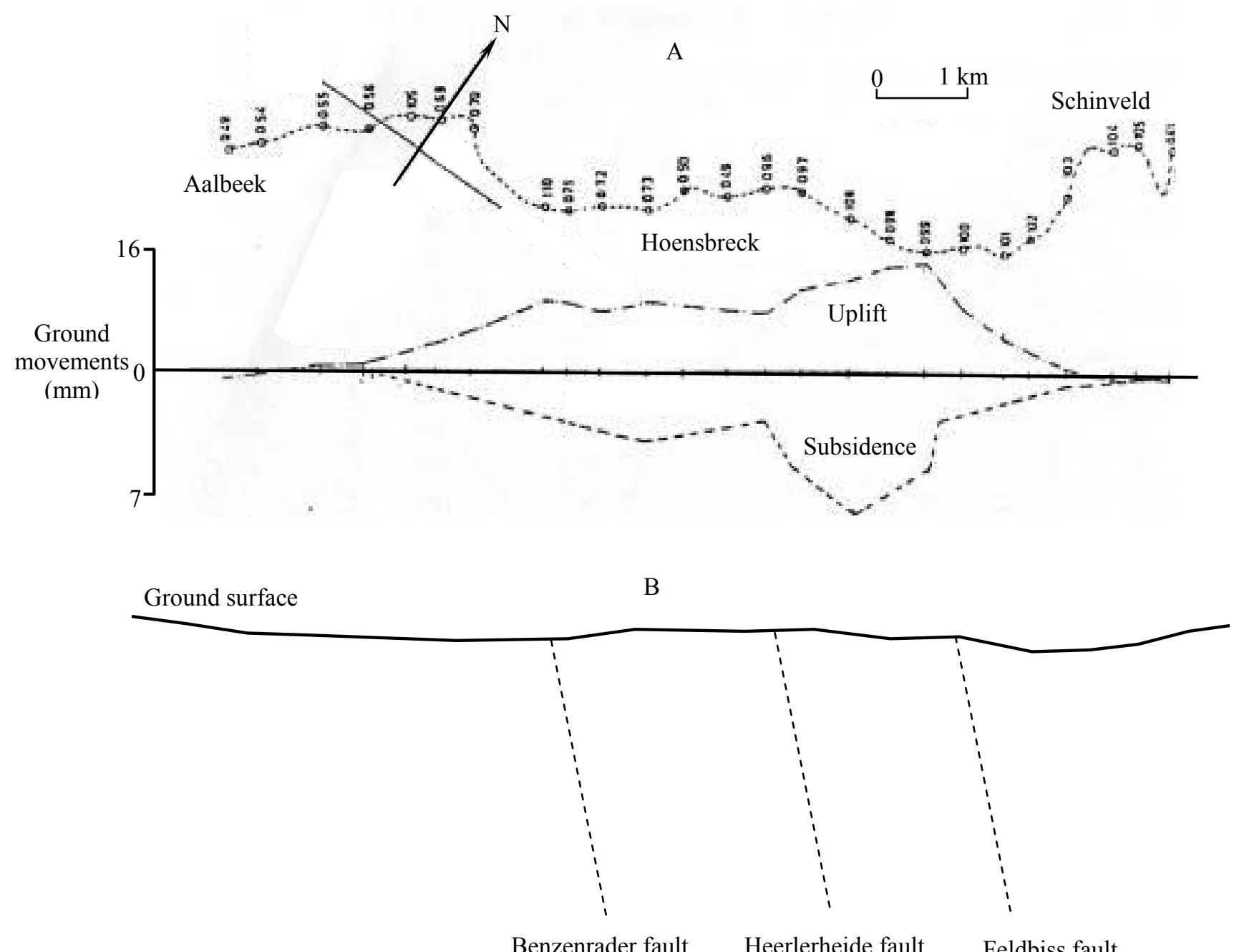

Figure 9 (A) Profile showing maximum vertical subsidence and uplift, as a result of minewater rebound. (B) Schematic illustration to show the relative position of post mining ground uplift in the Aalbeek, Hoensbroek and Schinveld region, southern, Limburg coalfield, (modified after Bekendam \& Pottgens 1995). 
A

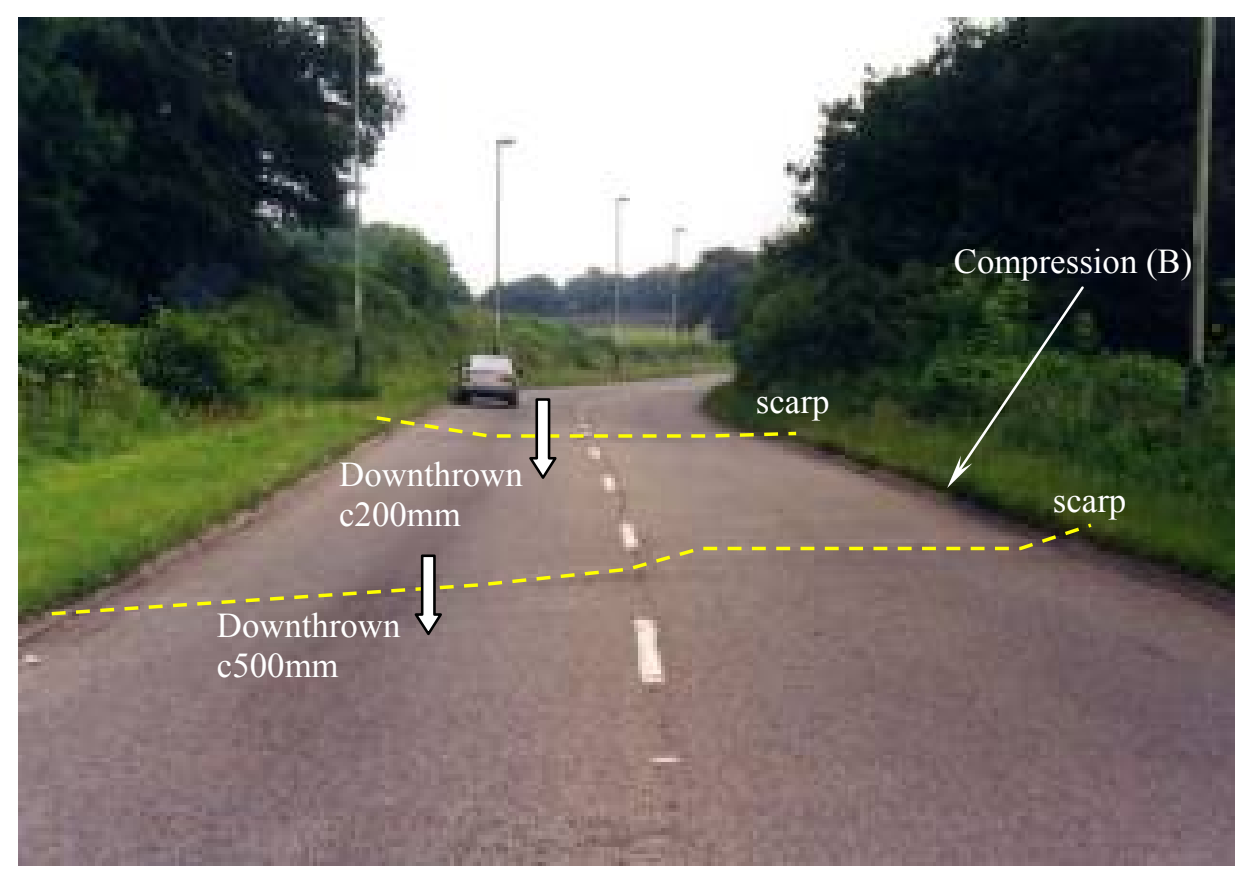

$\mathrm{B}$

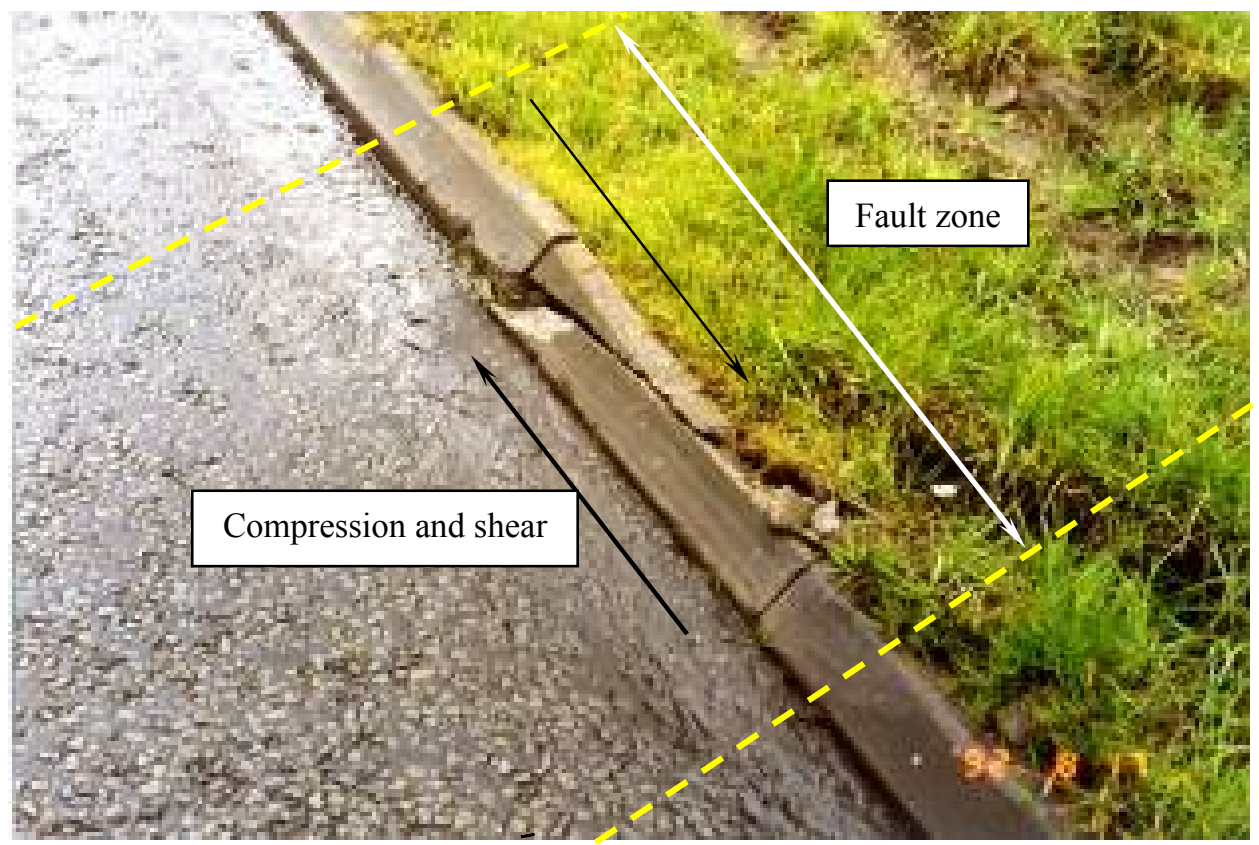

Figure 10. (A) Post mining residual subsidence and fault reactivation ground movements, (B) accompanied by high compressive strains within the fault zones, 10 years after mining ceased, causing damage to the Nelson to Gelligaer road, South Wales (after Donnelly 1994). 


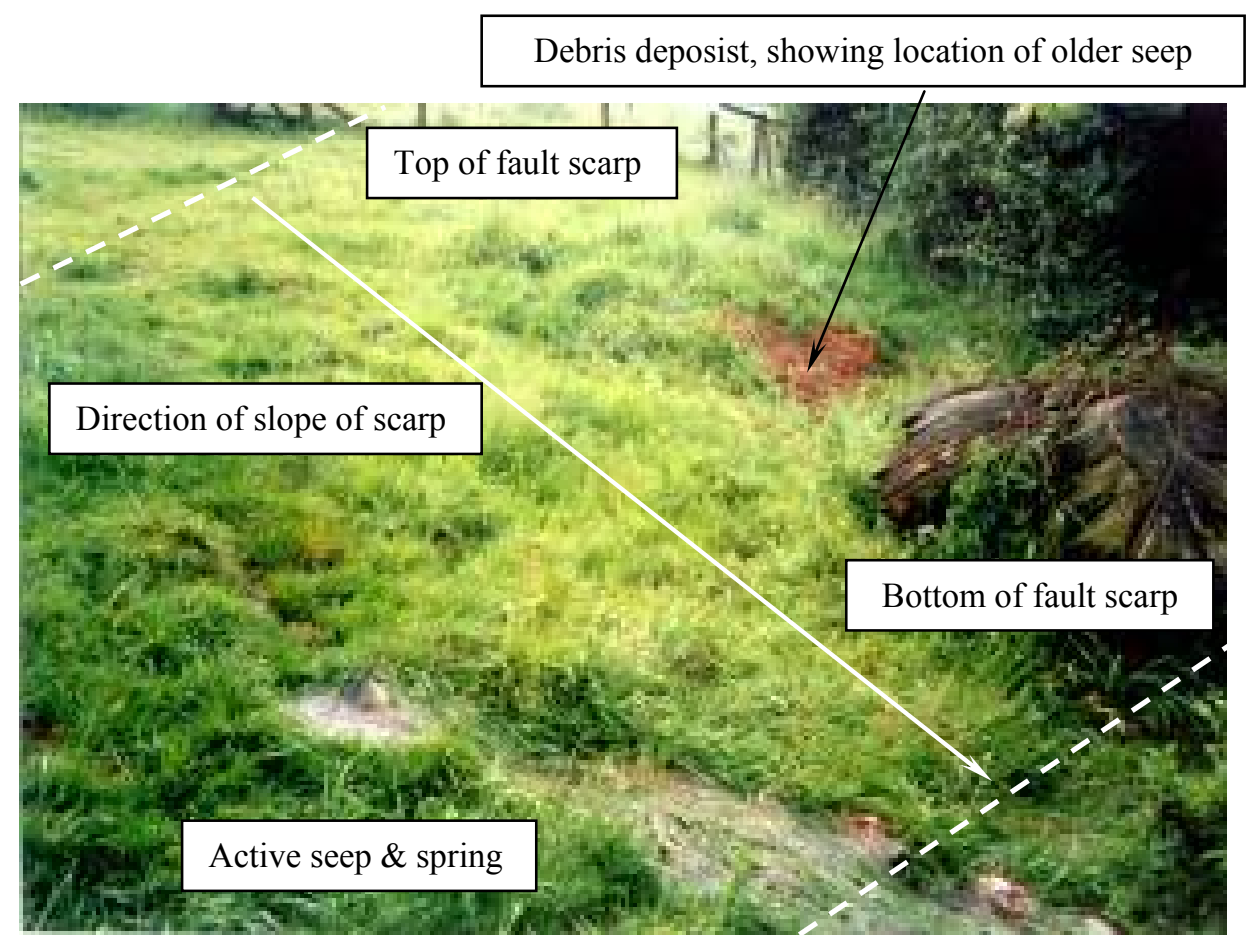

Figure 11 Relative apparent vertical component of a reactivated fault scarp, $1.5 \mathrm{~m}$ high. The discharge of groundwater and small debris cones along the scarp face during periods of prolonged heavy rainstorms as a result of the upwelling of groundwater along the fault. The Crowcrofts Fault scarp, adjacent to Wedgewood Drive and Barlaston gas main, Barlaston, Staffordshire (after Donnelly 1994). 
A

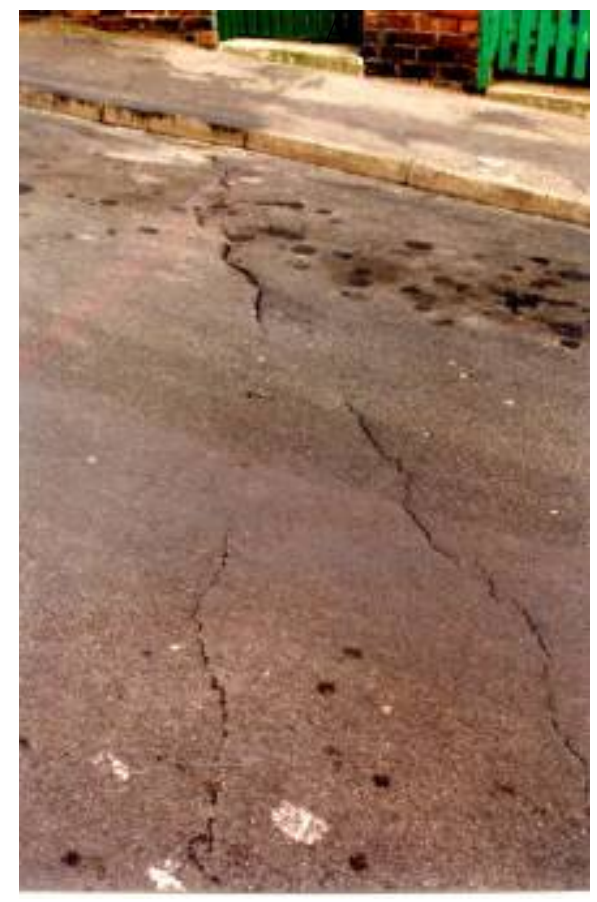

C

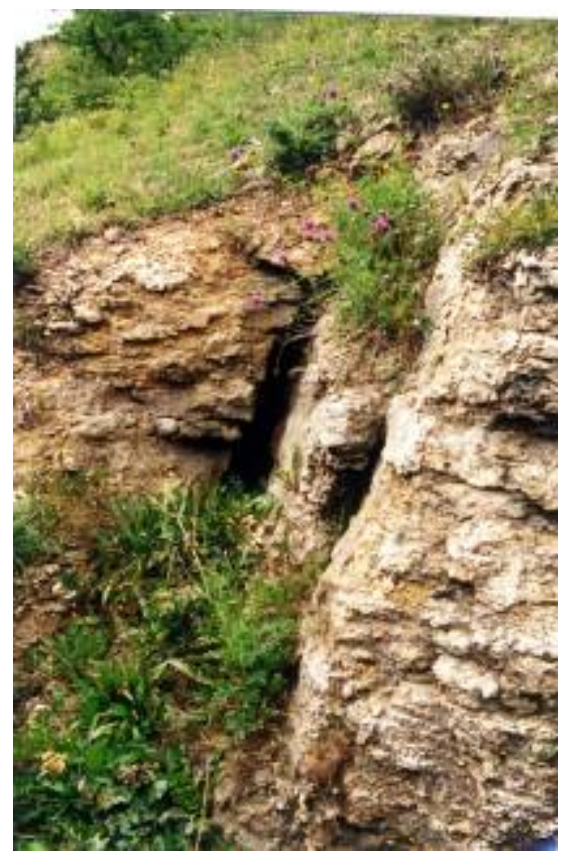

B

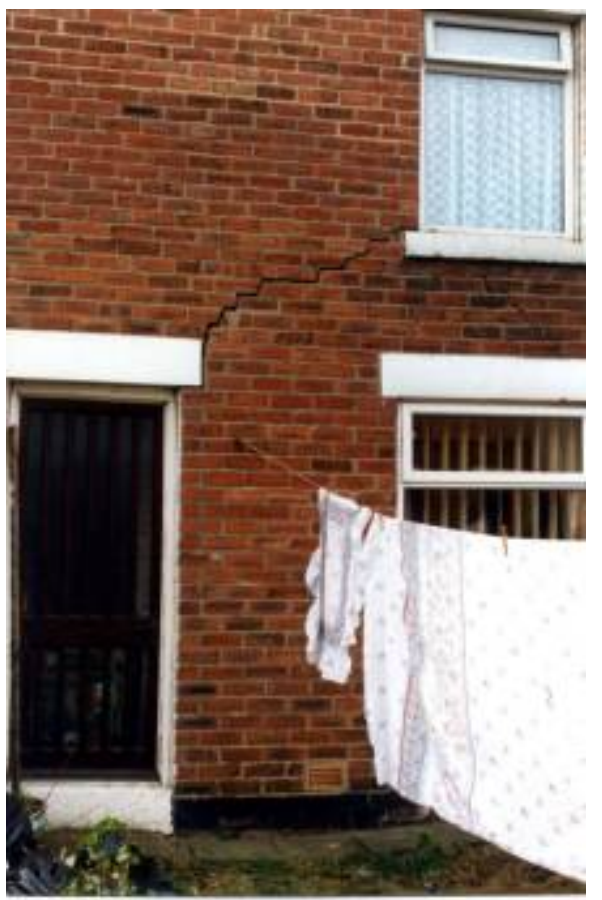

D

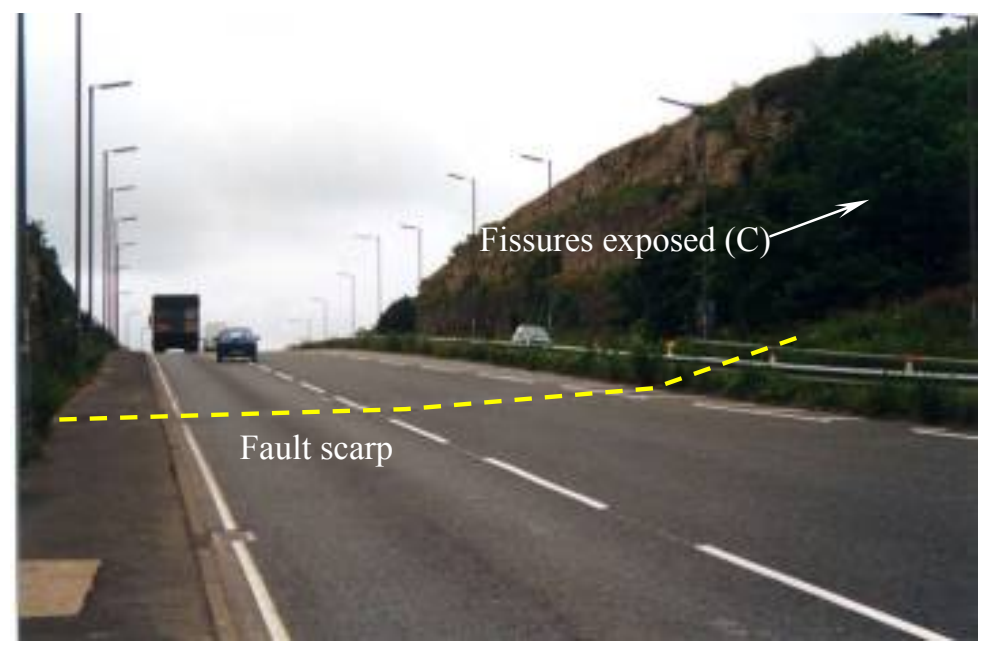

Figure 12 (A \& B) Small graben generated across a road and damage to terraced houses, Easington, County Durham (C \& D) Fissures exposed in the cutting walls and carriageway of the A690 road, which generated a small scarp across both sides of a dual carriageway, Houghton-le-Spring, County Durham (after Donnelly 1998). 